\title{
AS CATEGORIAS FREIREANAS E A EDUCAÇÃO POPULAR NA PERSPECTIVA DO FILME TRISTEZA DO JECA ${ }^{1}$
}

\author{
Juscimar Maria de Paula ${ }^{2}$ \\ Armindo Quilicci Neto ${ }^{3}$ \\ Universidade Federal de Uberlândia - UFU
}

\section{RESUMO}

Esta pesquisa, situada no âmbito da História da Educação Brasileira, tem como vertente o cinema enquanto mecanismo de Educação Popular. Para tanto, o objetivo consiste em identificar as categorias freireanas: diálogo, conscientização e libertação que permeiam essa obra. Assim, propomos a problematização a partir das seguintes questões: Como essa película colabora para a compreensão da cultura educacional brasileira nas décadas de 1950 e 1960? Qual é o conceito de educação que a transpassa? Assim, a relevância do estudo fundamenta-se na defesa da análise dos elementos cômicos ou mesmo satíricos da obra cinematográfica Tristeza do Jeca, como mecanismo revelador de importantes fatores do processo de construção de um período da história do Brasil. Associa-se a isso o fato de ser uma pesquisa inédita no âmbito da História da Educação brasileira, pois pouquíssimas são as pesquisas sobre a produção cinematográfica de Mazzaropi, e nenhuma relaciona-se ao Filme Tristeza do Jeca como mecanismo de educação Popular. Quanto aos procedimentos metodológicos, esclarecemos que trata-se, de uma pesquisa qualitativa, de cunho documental, pautada na consulta e análise da filmografia de Mazzaropi.

Palavras-chave: História da Educação; Tristeza do Jeca; Educação Popular.

\section{FREIRE'S CATHEGORIES AND THE POPULAR EDUCATION IN THE PERSPECTIVE OF THE MOVIE "TRISTEZA DO JECA"}

\begin{abstract}
This research, set in the scope of Brazilian Education History, has as direction the movies as a way to Popular Education. Thereof, the goal is to identify the categories according to Freire: dialogue, awareness and liberation that permeate the work. Therefore, this research proposes to work from the following matters: how does the movie help understand the Brazilian educational culture in the 1950s and 1960s? What educational concept does it exceed? The importance of the study lays in the defense of the comic elements or even satirist of the movie "Tristeza do Jeca", as a revealing mechanism of important factors of the construction process of a Brazilian historical period. It can be added that it is a inedited research in Brazilian Educational History. There are few researches about Mazzaropi's cinematographic production and none is related to "Tristeza do Jeca" as a Popular Education mechanism. As to the methodological process, we clarify that it is a quality improvement, done as a documentary, ruled by the consult and the analysis of Mazzaropi's filmography.

Key words: Educational History; Tristeza do Jeca; Popular Education.
\end{abstract}




\section{Introdução}

O filme Tristeza do Jeca, além de ser uma representação da sociedade brasileira, é o testemunho da sociedade no qual foi produzido. Afirmamos isso porque acreditamos que nenhuma produção cinematográfica, embora retrate as particularidades da vida, os sentimentos e comportamentos dos indivíduos, a sua interioridade subjetiva, não deixa de expressar a sociedade de uma época. Suas imagens são repletas de historicidade, tornandose, por sua função social, testemunhos visuais de uma dada época e lugar. Como tais, não só retratam o espírito de uma época, permitindo-nos a compreensão de como os homens e mulheres constroem a vida social, uma vez que expressam e deixam registrados para a posteridade práticas sociais, modos de pensar, valores, símbolos, sentimentos, comportamentos, tensões, expectativas, temores, próprios de uma determinada sociedade, como também são fontes de informações sobre determinadas mudanças. Isso nos permite considerar que o nosso objeto de estudo pode se transformar num importante manancial para que o povo brasileiro conheça seu momento histórico, suas relações sociais, como e por que os homens se educam, subsidiando a reconstrução histórica do objeto educação, e, com isso construam sua identidade nacional.

Sabemos que a construção de uma identidade nacional surge do sincretismo de vários elementos: étnico, linguístico, religioso, social, cultural, político e econômico. Portanto, a identidade é a definição de um grupo sobre si mesmo e sua trajetória, social, cultural e histórica, ressaltando suas diferenças sobre o outro. De acordo com Ortiz (1992), como a memória nacional, a identidade de uma nação vincula-se à história e pertence ao domínio da ideologia, simbolizado pelo Estado.

O Estado é esta totalidade que transcende e integra os elementos concretos da realidade social, ele delimita o quadro de construção da identidade nacional. É através de uma relação política que se constitui assim a identidade; como construção de segunda ordem ela se estrutura no jogo da interação entre o nacional e o popular. (ORTIZ, 2003, p. 138139).

Desse modo, o cinema é essencial na mediação dessas representações, exercendo o papel de uma poderosa ferramenta, capaz de promover a disseminação de práticas sociais e culturais. Além disso, auxilia na criação da identidade nacional de um grupo produzido por meio de uma visão de homem e mundo, o qual faz parte de uma sociedade. $\mathrm{O}$ ambiente cria identidades e, dessa forma, as reconstruções produzidas pelos filmes disseminam e compõem a identidade do grupo que está nela representado. Por meio da análise de cinematografias nacionais, podemos vislumbrar traços da imagem sociocultural brasileira, bem como os possíveis estereótipos relacionados à identidade nacional.

Nesse contexto, deparamo-nos com o filme Tristeza do Jeca, um gênero fílmico exclusivamente brasileiro, produzido na década de 1960, por Mazzaropi . Esse diretorautor, empresário, ator, chamado Amácio Mazzaropi, durante mais de vinte anos, foi um dos principais produtores do cinema nacional, com atuação em 32 filmes e personificou uma das figuras mais marcantes da cinematografia brasileira: o Jeca, figura representativa do caipira brasileiro.

A personagem central do filme Tristeza do Jeca, o Jeca ${ }^{4}$, configurava o momento desenvolvimentista pelo qual passava o povo brasileiro, sem perder os elementos culturais que formam sua essência, ou seja, adquiria nova configuração à medida que o tempo passava, mas fortalecia a memória do que é efetivamente: "a síntese das origens do povo que retratava, a partir da síntese das origens do trabalhador brasileiro". (BARSALINI, 
2002, p. 25). Portanto, essa obra cinematográfica identifica-se com a população brasileira, reconhecida nos personagens nela representados. Geralmente, seu público é carente em sua formação educacional formal; são pessoas para as quais as imagens são, muitas vezes, a única possibilidade de acesso às informações. (BARSALINI, 2002).

Essa obra cinematográfica foi produzida e lançada no de 1961. Nela, o "Jeca", personagem representada por Mazzaropi ${ }^{5}$, é um líder entre os colonos e vive com sua família e outros camponeses na fazenda do Cel Felinto (Nicolau Guzzardi) o qual disputa a prefeitura de uma pequena cidade do interior com o Cel Policarpo (Genésio Arrunda), um homem de aparência frágil e de idade avançada, cuja campanha é liderada pelo Cel Bonifácio, cujo objetivo é manter-se no poder. "Os camponeses são obrigados a votar em seus "patrões" para continuar a ter moradia e trabalho, ou seja, o filme possui como eixo principal a troca de votos." (FRESSATO, 2009, p. 188). Além disso, em busca dos votos dos eleitores, é usado todo o tipo de artimanhas e violência, como compra de voto, sequestro, ameaças e a promessa de casamento entre a ingênua e analfabeta filha do "Jeca" e Sérgio (Augusto César Vanucci), o filho do Cel Bonifácio, um rapaz da cidade grande, estudado, com o título de doutor. Destacamos, aqui, o papel de Mazzarapi como educador popular, pois, ao denunciar a realidade acima, ele a problematiza e sugere possibilidades. Assim, essa postura está de acordo com a proposta pedagógica freireana, que requer um educador problematizador, visto que se trata de uma pedagogia da pergunta, uma vez que "[...] ensinar não é transferir conhecimento, mas criar as possibilidades para sua produção ou sua construção". (FREIRE, 2004, p. 22).

Na proposta da Educação Popular ${ }^{6}$ há uma busca de uma emancipação que garanta aos aprisionados galgarem os degraus do conhecimento para se libertarem, mediados por aqueles que detêm os privilégios sociais, econômicos e políticos. É preciso, portanto, uma articulação dos que estão presos para que venham alcançar a libertação das cadeias opressoras. É justamente a necessidade dessa união entre os oprimidos como forma de alcançar a liberdade, que o filme Tristeza do Jeca apresenta, de modo sátiro, cômico e muitas vezes, dramático. A cena em que o coronel Felinto vai à casa do Jeca junto com alguns jagunços e ameaça despejá-lo, caso a sua filha Marina, continue com seu namoro com o Dr. Sérgio, ilustra a ideia da necessidade de união entre os oprimidos. Quando ele vai embora, os colonos vão para a choupana do Jeca para lhe prestarem solidariedade.

Contrário à proposição desenvolvimentistas da sociedade capitalista, o Jeca apresentado nesse filme se nega a trabalhar, contestando, de modo sutil, a ordem dominante. A primeira cena do filme, já citada por nós, mostra o Jeca dormindo na beira de um rio, enquanto todos os colonos, inclusive sua família, passaram o dia no campo trabalhando na lavoura de arroz.

Assim, no início dos anos 1960, no auge da ideologia nacional desenvolvimentista, o Jeca do filme, vai à contramão da ideologia dominante, que define o trabalho como máxima para a felicidade, mostrando um ritmo de trabalho próximo das necessidades do homem campesino. Apesar de o Jeca caracterizar o caipira de modo caricaturado, é evidente a intensão do filme de estabelecer uma crítica à sociedade vigente. Segundo Fressato

Devemos destacar ainda que, o "preguiçoso" Jeca é um personagem absurdo, em sua completa inatividade e inutilidade. Mazzaropi caricaturiza ao máximo, ridicularizando um dos aspectos mais importantes da ideologia desenvolvimentista, a glorificação do trabalho. Revelando, assim, que o filme tem uma lógica interna própria, independentes de seus efeitos comerciais. (FRESSATO, 2009, p. 181). 
A representação da política coronelista ${ }^{7}$, no filme, denuncia ao público que essa prática permanece viva em nosso país no ano de 1960. Analisando as cenas, identificamos o histórico dos chefes locais e suas relações de poder, e percebemos o quanto de coronelismo, mesmo que sob manifestações diferentes, nas atitudes cotidianas de imposição de poderes, presente nas décadas de 1950 e 1960, no interior de nosso país, amparada na concentração fundiária e na formação do latifúndio.

No filme Tristeza do Jeca, o coronelismo é personificado pelos personagens Cel Bonifácio, Cel, Felinto e Cel Policarpo. Esses "coronéis" mantinham seu poder alicerçado na posse da terra e de quem ali habitava, seus parentes, empregados, colonos e apadrinhados, os quais, para terem a garantia de emprego ou "proteção", precisavam provar sua lealdade, votando no coronel ou na pessoa que ele indicasse. A cena, a seguir, exemplifica essa situação. Nela, o Dr. Márcio, filho do coronel Bonifácio, vai à casa do Jeca, acompanhado por Vinícius (Roberto Durval), capataz de seu pai, pedir apoio para o candidato de seu pai a prefeitura local, o coronel Policarpo:

Dr. Márcio: Bem, Jeca. Eu gostaria que você pedisse para que seus amigos votassem no candidato de meu pai, o coronel Policarpo.

Jeca: Ocêis que sabe duma coisa? Eu num vou pidi nada não. Eu num tenho nada qui vê com a vida du zotô. (Pausa). E dispois, tá aí uma coisa qui homi direito num faiz.

Capataz Vinícius: O que é que homem direito não faz?

Jeca: Atraí o patrão.

Capataz Vinícius : Atraì?! É trair, do verbo trair.

Essa cena, como a do rapto do filho do Jeca, entre outras, revela ao público que o coronelismo, não apenas era vigente na zona rural do Brasil, como existiam políticos nas cidades do interior do país. Além disso, a fala do Jeca demonstra um comportamento ainda vigente em nossa sociedade, o voto visto como mecanismo de troca. Muitas pessoas ainda votam naquele candidato que lhe proporcionou alguma vantagem ou alguma coisa, ou que ainda vai lhe dar. Segundo Fressato, "o caipira votar num coronel, ou num candidato por ele indicado, não simboliza aceitar passivamente sua vontade e sim, dar conscientemente seu voto a um chefe poderoso de quem recebe ou irá receber algo". (FRESSATO, 2009, p. 188). No diálogo a seguir, continuação da cena citada, isso é explicitado para o público.

Dr. Márcio: Você podia ficar até rico Jeca.

Jeca: Vá prantá batata. Sua vó morreu na encruziada.

Capataz Vinícius: Eu tenho certeza que você vai pensar e vai dar uma resposta satisfatória.

Jeca: Nós num gostamô de política, dotô.

Dr. Márcio: Bem, deixo o senhor com a sua consciência.

Jeca: E guarde bem a sua dotô, pruquê o sinhô vai precisa dela, né?

Por acreditarmos que essa filmografia de Amácio Mazzaropi não pode ser compreendida apenas como um processo de comunicação cinematográfica, mas nos aspectos intrínsecos que a compõem, como um mecanismo de educação popular, propomos traçar um paralelo entre essa produção e a concepção de educação popular freireana. Para isso, elegemos as categorias de Paulo Freire diálogo, conscientização e libertação, as quais serão identificadas no filme Tristeza do Jeca, conforme o quadro abaixo: 
QUADRO 1 - As categorias freireanas no filme Tristeza do Jeca.

\begin{tabular}{|c|c|}
\hline $\begin{array}{l}\text { Categorias } \\
\text { freireanas }\end{array}$ & Cenas do filme \\
\hline Diálogo & $\begin{array}{l}\text { - Cena em que os filhos do Cel. Bonifácio e o seu capataz vão a casa do } \\
\text { Jeca; } \\
\text { - Cena em que o Cel. Bonifácio organiza um rodeio, com o único objetivo } \\
\text { de conseguir o apoio dos colonos. Ao qual, mesmo temerosos, } \\
\text { comparecem os camponeses da fazenda do Cel. Felinto, inclusive o Jeca e } \\
\text { sua família. E este é forçado a subir no palanque e apresentar seu apoio ao } \\
\text { coronel Policarpo, por meio de uma manipulação de palavras; } \\
\text { - Cena na qual o Jeca procura convencer os outros colonos, que temerosos } \\
\text { de perderem os empregos, cedem às ameaças do Felinto e se escondem } \\
\text { em seus casebres, para não ajudar na busca pelo seu filho Toninho que } \\
\text { fora raptado pelos capangas do Cel. Felinto. }\end{array}$ \\
\hline Conscientização & $\begin{array}{l}\text { - Cena, logo no início do filme Tristeza do Jeca, em que o Jeca é } \\
\text { interpelado por um grupo de colonos preocupados com as eleições } \\
\text { próximas; } \\
\text { - Cena em que o Jeca fica sabendo do rapto de seu filho pelo Cel. Felinto } \\
\text { e resolve ir a sua casa para pedir explicações; } \\
\text { - Cena em que os capangas dos coronéis, em busca de eleitores, } \\
\text { encontram uma velha senhora, negra, desdentada e analfabeta e oferecem } \\
500.000 \text { réis pelo voto de seu marido e seus filhos; }\end{array}$ \\
\hline Libertação & $\begin{array}{l}\text { - Cena que apresenta os colonos do Cel. Felinto indo para um rodeio } \\
\text { organizado pelo coronel Bonifácio, mesmo contra as ordens do "patrão"; } \\
\text { - Cena em que o Cel. Felinto fica sabendo que Marina, a filha do Jeca, } \\
\text { está de namoro com o Dr. Sérgio filho do Bonifácio, e logo compreende } \\
\text { que é uma manobra política do adversário. Em seguida, pede para seus } \\
\text { jagunços irem à vila dos colonos e ameaçá-los; } \\
\text { - Cena em que os colonos acompanham o Jeca à casa do Cel. Felinto; } \\
\text { - Cena que os camponeses estão depositando os votos na urna. }\end{array}$ \\
\hline
\end{tabular}

Destacamos aqui o filme Tristeza do Jeca como mecanismo de educação popular, pois as temáticas nele abordadas denunciam uma realidade, problematizam e sugerem possibilidades. Isso, de acordo com a proposta pedagógica freireana, requer um educador problematizador, visto que se trata de uma pedagogia da pergunta, uma vez que "[...] ensinar não é transferir conhecimento, mas criar as possibilidades para sua produção ou sua construção". (FREIRE, 2004, p. 22). Assim sendo, podemos refletir sobre a forma como pode acontecer a educação conscientizadora, ou ainda, a socialização de conhecimentos e pensamentos "libertadores". Portanto, é neste ponto que cabe a nossa reflexão em torno das 
categorias freireanas diálogo, conscientização e libertação, elementos imprescindíveis aquisição da autonomia.

\section{Diálogo}

A análise da trajetória histórica da humanidade permite-nos identificar homens e mulheres sendo subjugados por outros que possuem um determinado conhecimento, vistos como dominantes pela sociedade. Paulo Freire nos chama a atenção para essa situação de imposição experenciada por pessoas que perderam sua condição de sujeitos ativos da própria história, tornando-se objetos passivos de uma "ordem" social que os exclui do chamado a conhecer, a saber, a questionar, a decidir, a transformar. Em suas obras, ele propõe a adoção de uma educação que tenha como objetivo maior a valorização do homem em suas capacidades e possibilidades. Sua orientação educacional baseia-se na atuação política voltada a gerar posturas críticas perante as circunstâncias do mundo, tendo a dialogicidade como teoria fundamental. Pois somente "o diálogo fenomeniza e historiciza a essencial intersubjetividade humana; ele é relacional e; nele, ninguém tem iniciativa absoluta. Os dialogantes admiram um mesmo mundo; afastam-se dele e com ele coincidem; nele põem-se e opõem-se". (FREIRE, 1992, p.16).

Para Paulo Freire, o mundo humano é um mundo de comunicação: "o mundo social e humano não existiria como tal se não fosse um mundo de comunicabilidade fora do qual é impossível dar-se o conhecimento humano". (FREIRE, 1982, p. 65). Um conhecimento se origina no encontro entre pessoas e se faz histórico no diálogo. Por meio do diálogo, o ser humano analisa de modo crítico o mundo.

Assim, Freire nos propõe que o diálogo seja um meio de socialização de ideias responsáveis por criar, nos indivíduos, uma mudança comportamental, ou seja, a ação. Este diálogo é uma comunicação bidirecional, na qual todos os envolvidos têm direito à voz. Portanto, a comunicação com alguém sobre alguma coisa, a fim de produzir ou reconstruir conhecimento, não pode instaurar-se na negação da vocação humana de ser mais, porque não se baseia na ação de um homem sobre o outro, mas na comunicação entre homens compartilhando saberes a fim de transformar a si e o mundo, e o diálogo entre o Jeca, seus pares, e os opressores permeiam todo o filme Tristeza do Jeca. A cena em que os filhos do Cel. Bonifácio e o seu capataz vão à casa do Jeca, já referida por nós, evidencia que, no diálogo entre o caipira "ignorante" e os doutores da cidade, em que o Jeca, apesar de não saber o significado das palavras e nem pronunciá-las corretamente, não se submete ao mandonismo, conhecedor por experiência que aquele "falatório" é um mecanismo que objetiva convencê-lo a fazer algo. Vejam um trecho do diálogo, na cena, à qual nos referimos:

Dr. Márcio: Bem Jeca, durante a campanha, nós podemos por a sua disposição tudo o que for necessário.

Capataz Vinícius: A sua casa, por exemplo. Você precisa melhorar. Aqui não tem goteira?

Jeca: Num sinhô. Só pinga.

Capataz Vinícius: Você não tem uma ideia para dar para gente?

Jeca (rindo): Engraçado... ocê anda junto cum um dotô e vem pedi ideia pra eu? Há, há, há.

Dr. Márcio: É que eu não conheço a psicologia do caboclo, Jeca.

Jeca: Pisico, o quê?!

Capataz Vinícius: A psicologia.

Jeca (dirigindo-se a mulher): Vai pru fugão.

Volta-se zangado, para o capataz e o Dr. Márcio e diz: 
Jeca: Eu falei pro cêis, se fosse pra fala bestera nóis ficava lá nu campo. Lugá de animá é lá.

A dialogicidade requer que as pessoas se mantenham em uma relação de respeito diante da liberdade uns dos outros, ou seja, ela requer uma relação baseada na comunicabilidade e respeitabilidade, e não pela força da opressão e submissão. Portanto, na concepção freireana, o diálogo é condição humana, dialogar é humanizar-se, é existenciar-se. Segundo o autor, “existir, humanamente, é pronunciar o mundo, é modificálo. O mundo pronunciado, por sua vez, se volta problematizado aos sujeitos pronunciantes, a exigir deles novo pronunciar". (1992, p.78).

Sendo assim, necessitamos sair do "antidiálogo" e estabelecer o diálogo, para que possamos evoluir de uma consciência ingênua para um pensamento crítico. Pois

o diálogo é uma relação horizontal de A com B. Nasce de uma matriz crítica e gera criticidade. Nutre-se do amor, da humildade, da esperança, da fé, da confiança. Por isso só o diálogo comunica. [...] enquanto o antidiálogo que implica uma relação vertical de A sobre B, é o oposto a tudo isso. (FREIRE, 1986, p.107-108).

É essa relação horizontal que o Jeca estabelece nas cenas em que dialoga com seus opressores. Em todos os momentos, ele se mostra consciente das intenções de seus intelecutores. Escolhemos o início da cena em que os filhos do Cel Bonifácio vão à casa do Jeca tentar conseguir o seu apoio político para evidenciar essa questão.

Dr. Márcio: Bem, Jeca, o assunto que me traz a sua casa...

Jeca: Pera aí.

Jeca se levanta, vai até a porta de sua casa e a abre de supetão, deixando cair dentro dois colonos que estavam ouvindo atrás da porta.

Jeca: Dotô, num repara. O Jamanta (referindo-se a um dos colonos) é anarfabeto de pai e mãe.

Entra o outro filho do Coronel Bonifácio, o Dr. Sérgio

Dr. Sérgio: O senhor como um homem honesto, sincero, trabalhador, deve compreender que o coronel Policarpo é o único que traz a política de defesa do homem do campo.

Jeca: Pode continuá. (dá um tragada no cachimbo).

Dr. Sérgio: Continuando, meu amigo Jeca, eu dizia que para o nosso candidato sair vitorioso no pleito, se faz necessário que você convença seus amigos a votar em nossa causa.

Jeca: Engraçado, os dois (referindo-se aos dois filhos do Bonifácio) tão falanu a mesma coisa. Dirigindo-se ao Dr. Sérgio, diz: Ocê entrô aqui pra repiti tudo. Há, há, há.

Dr. Sérgio aborrecido se levanta e diz:

Dr. Sérgio: O problema é de vocês. Passar bem Jeca. ( Em seguida, vai embora).

Jeca: Eu num vou passa nada. Quem passa é ocê (dirigindo-se a sua esposa).

O Cel. Bonifácio, ao compreender que não será um intento fácil manipular o Jeca, aceita a sugestão de seu capataz Vinícius, de pedir que seu filho Sérgio simule um noivado com Marina, a filha do Jeca. O Cel Felinto, por sua vez, temeroso de perder os votos de seus empregados devido a esse "arranjo político", ordena que seu jagunço ameace os camponeses e posteriormente ele vai à casa do Jeca ameaçá-lo pessoalmente. Segundo 
Fressato (2009, p. 191), “o Cel Bonifácio opta pela persuasão e as promessas; já Felinto, representa o coronel que se utiliza de ameaças, da violência e do medo dos camponeses para conseguir o que almeja".

Identificamos, nas cenas citadas, a crença que os coronéis tinham acerca do poder de manipulação que exerciam sobre os camponeses. Nelas, evidencia-se o processo de manipulação que conduz à massificação do indivíduo. A manipulação é "apresentada como forma de dirigismo, que explora o emocional dos indivíduos, inculca neles aquela ilusão de atuar ou de que atuam na atuação de seus manipuladores". (FREIRE, 1982, p. 42). Destacamos, como representativa dessa situação, a cena em que o Cel Bonifácio organiza um rodeio, com o único objetivo de conseguir o apoio dos colonos. Nesse rodeio, mesmo temerosos, comparecem os camponeses da fazenda do Cel. Felinto, inclusive o Jeca e sua família. E este é forçado a subir no palanque e apresentar seu apoio ao coronel Policarpo, por meio de uma manipulação de palavras:

Cel Bonifácio (falando alto): O Jeca está do lado do cel Policarpo!

Jeca: Eu num tô do lado de ninguém.

Capataz Vinícius (falando ao ouvido do Jeca e mostrando que este está posicionado ao lado do cel Policarpo): Não diga isso! Então você não está do lado do cel Policarpo?

Jeca: Há, tá. Eu tô.

Capataz Vinícius (falando alto): O Jeca, você está do lado do cel Policarpo?

Jeca (olha para o cel Policarpo do seu lado): Tô!

Aplausos

Cel Bonifácio (falando alto): Desde já sentimo-nos vitoriosos porque o Jeca apoia o cel Policarpo.

Jeca: Pera aí gente! Cêis ficam falanu umas bobage, que eu num tô intendenu nada. Eu num apoio, ninguém. Quem que apóia?

Capataz Vinícius (falando apenas para o Jeca ouvir): Jeca, não diga isso! Então se o coronel Policarpo levar um tropeção e cair você não apoia ele? Jeca: É craro que eu apoio.

Capataz Vinícius (falando alto, para ser ouvido por todos): Jeca, você não apoia o cel Policarpo?

Jeca (falando alto): Apoio!

Aplausos.

A figura 1 representa a cena em que o Jeca é carregado para o palanque contra a sua vontade. Nessa imagem, é possível observar a filha do Jeca sendo "cortejada" pelo filho do Cel. Bonifácio. 
FIGURA 1 - o Jeca sendo carregado para o palanque.

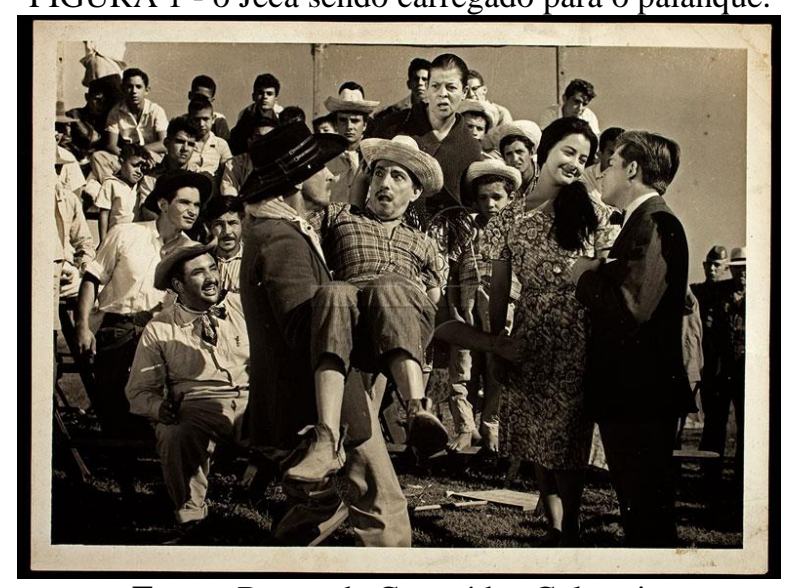

Fonte: Banco de Conteúdos Culturais.

Isto posto, necessário se faz que nos afastemos da situação de acomodação e adotemos uma postura de esperança na aquisição da libertação. É esta esperança, "exigência ontológica dos seres humanos", $(2005$, p.30), que se opõe ao desespero que, para Freire, "é uma forma de silêncio, uma maneira de não reconhecer o mundo e fugir dele". (FREIRE, 1980. p. 84). O desespero e o silêncio impedem a ação cultural libertadora. Para este autor, "os limites da ação cultural se encontram na realidade opressora mesma e no silêncio imposto às classes dominadas pelas classes dominantes. [...] a ação cultural pela liberdade enfrenta o silêncio [...]”. (FREIRE, 1980, p.91).

Compreendemos que os indivíduos precisam se emancipar pela aquisição da consciência crítica. Os meios de comunicação, a mídia de modo geral, são usados, muitas vezes, como instrumentos de manipulação das massas. Portanto, na visão da proposta de emancipação, analisar comunicação dialógica requer em bidirecionalidade. Os homens e mulheres precisam adotar uma visão crítica, uma postura questionadora, para que não sejam manipulados pelos discursos alienantes da mídia.

À medida que os grupos percebem na discussão o que há de enganoso na propaganda - por exemplo, uma marca de cigarros, fumados por uma bela moça de biquíni, sorridente e feliz, e que com seu sorriso, sua beleza e seu biquíni nada têm a ver com os cigarros -, descobrem na primeira fase a diferença entre educação e propaganda. Preparam-se, assim, para perceber os mesmos enganos na propaganda ideológica ou política, no uso de "slogans". Capacitados para a crítica, estarão armados para a "dissociação de ideias" evocada por Huxley. (FREIRE, 1980, p.48).

No filme Tristeza do Jeca, analisado nesta pesquisa, percebemos a existência dessa mesma relação, no sentido de que eles propõem que, por meio do diálogo, se torne possível a conscientização do povo quanto aos princípios de igualdade e solidariedade, de sua posição diante da vida e, a partir dessa conscientização, seja possível a libertação das práticas de opressão que permeiam todas as relações na sociedade capitalista. Vejamos com o diálogo, a seguir, retirado da cena do filme analisado, na qual o Jeca procura convencer os outros colonos, temerosos de perderem os empregos, cedem as ameaças do Felinto e se escondem em seus casebres, a não ajudarem na busca pelo seu filho Toninho que fora raptado pelos capangas do coronel Felinto. A cena mostra o Jeca, caminhando no meio da pequena vila, desalentado, batendo na porta das choupanas e chamando pelos companheiros de infortúnio. Bate em uma porta e diz: 
Jeca: Nhá Antônia, me ajude!

Nhá Antônia: Vá embora Jeca. Tamu tudo sem serviço, e por sua causa. Jeca: Eu num tenho curpa gente! Nóis sempre fumo amigo. Eu quero que ocêis ajuda a procurá meu fio! Gente mi ajude!

Jeremias: Nóis num queremu aburricimento com gente do Filinto. Ocê procuro increnca, agora guenta sozinho.

Jeca: Ocêis precisa mi ajudá a procura meu fio. Até os fio do coroné Bonifácio tá procuranu, nóis num vive sozinho.

Nhá Antônia: Nóis num queremu mais complicação cum Felinto. Ele vai si vingá de todo mundo!

Jeca: Minha gente, desde que cheguemu aqui, nóis trabaiemu junto. E junto nóis cunstruímu nossas cazinhas. Sempre fumu bons amigu, principarmente na hora da necessidade. Vamu, genti! Tivemu dia de sacrifício, mas também juntu, passemu tantas noites festanu, bebenu, rino, cantano... se lembra? Quando nóis cheguemu aqui, aqui num tinha nada. Pouco a pouco a coisa foi cresceno, e foi cresceno, por quê? Porque nóis foi unido pessoa. Lembra das festa que fizemo junto no finá das coietá? E eu sempre dava tudo que tinha pra ajuda ocêis. Fui eu que te acompanhei pra pedi a mão da Rosinha do Mané, Tião. E quando seu fio tava duenti, eu fui correnu buscar o médico. E quem foi que ajudô nas dispesas do batizado de sua fia, Matheus? Quem foi? Se ocêis tão cum medo de perder o impregu, é bobage. A minha fia vai casá com o fio do coroné Bonifácio, eu arranjo serviço pro cêis. Eu arranjo serviço pro cêis! (grita).

Os colonos permanecem calados e o Jeca, desalentado, dirige-se para sua casa. Em seguida, os colonos vão saindo lentamente de suas choupanas, pensativos e preocupados, e um deles orienta:

Colono: Ei, pessoá! Agora num é hora de guarda rarva. Vamu ajuda o Jeca e seja o que Deus quiser!

Os demais colonos os seguem e juntos vão a casa do Jeca.

Jeremias: Jeca! Ô Jeca!

Jeca: $O$ qui é qui é?

Jeremias: Nóis resorvemu ajuda ocê a procura seu fio.

Matheus: Nóis vamu acha seu fio hoje de quarquer jeito.

Jeca: Então vamu.

Portanto, tanto para Freire quanto para o "Jeca", a palavra/diálogo é sinônimo de vida, capaz de promover a ação, base para adquirir a conscientização.

\section{Conscientização}

Com a discussão anterior, vimos que o diálogo e a comunicação são essenciais para que os seres humanos desenvolvam uma compreensão efetiva do mundo. Isso porque é por intermédio da comunicação que ocorrem as socializações das significações entre os indivíduos. Logo, a compreensão do mundo resulta do contato de homens e mulheres com o mundo, passando pela interação entre eles. Assim, incentivar a comunicação entre os sujeitos é promover a aquisição do conhecimento e, consequentemente, a tomada de consciência. Segundo Paulo Freire, a consciência humana ocorre a partir do jogo dialético das relações homem-mundo. Relações em que consciência e mundo se dão simultaneamente. De acordo com ele: 
Na verdade, não há eu que se constitua sem um não eu. Por sua vez, o não - eu constituinte do eu se constitui na constituição do eu constituído. Desta forma, o mundo constituinte da consciência se torna um mundo da consciência, um percebido objetivo seu, ao qual se intenciona. (FREIRE, 1992, p.71).

Dessa forma, para Paulo Freire, há uma simultaneidade entre o mundo e a consciência. Ao fazer essa afirmação, ele está se referindo ao mundo humano, mundo cultural, permeado de significações construídas e desconstruídas continuamente pela ação humana. Isso porque Freire, influenciado pelo materialismo histórico dialético e pelo existencialismo de Sartre, ensina-nos que a consciência humana é precedida pelo mundo físico, natural. Nessa concepção, o homem primeiro existe para, depois, tornar-se consciente de si mesmo e do mundo. Assim, a consciência não precede o mundo e o mundo não precede a consciência.

Logo, a ação dialética advinda das relações entre o ser humano e o mundo é a base da reflexão freireana sobre consciência, somente mediante esse jogo dialético é que acontece a apropriação de consciência do mundo pelo homem. É na práxis, nas ações diante dos desafios impostos pela vida, que o homem toma consciência de si, dos outros e do mundo. "A conscientização implica, pois, que ultrapassemos a esfera espontânea de apreensão da realidade, para chegarmos a uma esfera crítica na qual a realidade se dá como objeto cognoscível e na qual o homem assume uma posição epistemológica". (FREIRE, 1980, p.15).

A intencionalidade é outro aspecto decisivo na concepção freireana de consciência. Segundo ele, toda consciência é sempre consciência de alguma coisa. Ele nos esclarece que será pelo desenvolvimento de uma consciência crítica e não ingênua que seremos capazes de analisar a realidade, conhecê-la e transformá-la, pois a consequência da conscientização é o compromisso dos seres humanos com o mundo, já que, criticamente conscientes de nossa realidade de opressão, seremos capazes de realizar uma ação que objetive sua superação. Quando isso ocorre, o ser humano "se politizará a si mesmo". (FREIRE, 1980, p. 26). E o que vemos na cena, logo no início do filme Tristeza do Jeca, em que o Jeca é interpelado por um grupo de colonos preocupados com as eleições próximas. Vejamos;

Jamanta ${ }^{8}$ : A vida vai meiorá se nóis votá no Policarpo.

Jeca: Ocêis querem pará de enchê minha cabeça com esse trem de pulítica?! Gente, entra prefeito... sai prefeito, e ocêis tão se queixando. Ocêis querem é viver a custa do governo. Faiz que nem eu, trabaiá!

Jamanta: Bonifácio tá falanu pra votá no coroné Policarpo.

Jeca: E daí?

Jamanta: E daí que ele é mais honesto.

Jeca: Honesto?! Parece que ocêis num inxerga nada! Num tá vendo que quem vai manda na prefeitura é o Bonifácio?! O coroné Policarpo, coitado, parece um ford de bigode... queimando óleo... bateno o pino.

O comportamento do Jeca nos mostra claramente que a "consciência é condicionada pela realidade, assim a conscientização é um esforço através do qual, ao analisar a prática que realizamos, percebemos em termos críticos o próprio condicionamento a que estamos submetidos". (FREIRE, 1981, p.85). 
Entendemos que, para o Jeca, assim como para Paulo Freire, conscientização consiste no aprofundamento da consciência crítica. É o processo pelo qual superamos a consciência ingênua, pela qual a nossa compreensão da realidade ocorre de modo espontâneo, e passamos para "uma esfera crítica na qual a realidade se dá como objeto cognoscível e na qual o homem assume uma posição epistemológica". (FREIRE, 1980, p. 26). Compartilhando do pensamento freireano, o Jeca concebe conscientização como o processo de aquisição de saberes autênticos acerca das condições materiais vivenciadas pelo ser humano. O movimento de transformação da prática social do indivíduo requer, a priori, uma mudança na sua concepção de mundo, ele precisa exercitar práticas que condigam com a vocação ontológica de todo ser humano, é o ato de vencer a situação desumanizadora na qual está inserido.

Portanto, habita na consciência humana a possibilidade concreta de transformar os fenômenos naturais em proveito próprio. A mudança a que nos referimos é tanto dos objetos materiais, que são responsáveis pela satisfação das necessidades básicas do ser humano, como, de modo específico, da organização das diferentes instâncias de nossa existência. Isso ocorre porque o ser humano é o único "capaz de captar dados da realidade". (FREIRE, 1986, p.105). Por isso, nenhum homem pode ser considerado absolutamente ignorante, ainda que não possa também ser considerado absolutamente sábio.

Entretanto, a tomada de consciência advinda de uma aproximação espontânea da realidade, para Paulo Freire (1980), não pode ser considerada conscientização, porque ela se refere a um desenvolvimento ingênuo e não crítico de tomada de consciência. Para ele, "a conscientização é um compromisso histórico", pois requer que sejamos comprometidos com o mundo e, assim, com nós mesmos, capazes, desse modo, de refazer o mundo e a nossa própria história. Nessa perspectiva, a conscientização transcende a relação consciência/mundo, possibilitando que o ser humano assuma "uma posição utópica frente a mundo". (FREIRE, 1980, p. 26-27).

É essencial observar que, para Paulo Freire, "a conscientização não pode existir fora da práxis, sem o ato ação-reflexão. Está unidade dialética constitui, de maneira permanente, o modo de ser ou de transformar o mundo que caracteriza os homens". (FREIRE, 1980, p. 26). Com base nessa concepção dialética, vemos que um indivíduo que experiência o estágio de conscientização é aquele que empreende uma eterna busca acerca da razão de ser das coisas, agindo sobre elas de modo transformador. Dessa forma, a realidade do ser humano precisa ser compreendida como algo em permanente construção, em que o sujeito, por meio de sua práxis, atue de modo decisivo. A conscientização é o ponto de partida da evolução crítica do pensamento, por meio da qual ocorre o desvelamento da realidade e finda na práxis, ação e reflexão, em uma eterna tomada de consciência. E é isso que ocorre na cena em que o Jeca fica sabendo do rapto de seu filho pelo Cel. Felinto, e resolve ir à casa dele pedir explicações. Os outros camponeses, sabedores dos atos de violência do coronel, temem pela vida do Jeca e tentam impedi-lo; entretanto, não conseguem. Com a chegada do Jeca, na sede da fazenda, estabelece-se o seguinte diálogo:

Cel. Felinto (rodeado de jagunços): Jeca, eu sequestrei seu filho porque você foi ao rodeio, e ainda levou os outros empregados.

Jeca: Meu fio num tem nada cum isso. O sinhô num devia si vingá numa criança. Se nóis fumo na festa, num foi por pulítica, nóis queria si diverti.

Cel. Felinto: Quer saber de uma coisa? Seu filho só será devolvido depois das eleições.

Filó: Pelo amor de Deus, eu num posso ficá sem meu fio. (choro). 
Jeca: Isso é mardade! Num é porque o sinhô tem dinheiro que vai fazê o que qué cum nóis não.

Cel. Felinto (gargalhando): Há, há, há. Mais uma razão para vocês trabalharem pela minha vitória. Depois das elições vocês voltem aqui. (entra em sua casa).

O Jeca tenta ir atrás do cel. é um dos jagunços impede sua passagem e diz:

Jagunço: Sai fora sujeira!

Jeca: Eu sô sujo nas ropas e ocês é sujo na consciência.

Nesse sentido, para Paulo Freire, a conscientização da realidade histórica significa analisar duas estruturas predominantes e antagônicas: o opressor e o oprimido, cuja relação determina a realidade em seus inúmeros contextos. Além disso, a teoria freireana denuncia essa realidade e nos apresenta a práxis libertadora como mecanismos pelos quais venceremos os opressores.

No filme Tristeza do Jeca, vemos a denúncia que a prática do coronelismo, curral eleitoral e voto de cabresto, comuns ao estudarmos a história do Brasil, ainda faziam parte do contexto de muitas cidades do interior do Brasil nas décadas de 1950 e 1960. Nessa película, são apresentadas, literalmente, cenas em que os homens, no dia da eleição, são separados das mulheres (elas não votavam) e conduzidos para um curral próximo ao lugar de votação no qual são contados e só saem para votar sob o olhar do coronel, seu patrão. Entretanto, Mazzaropi nos mostra que, apesar de demonstrarem submissão e ingenuidade, "os caipiras" são conscientes das manobras políticas e conseguem ter poder de decisão. Na cena em que os capangas dos coronéis, em busca de eleitores, encontram uma velha senhora, negra, desdentada e analfabeta e oferecem 500.000 réis pelo voto de seu marido e seus filhos, isso fica bem claro.

Capanga do Cel Bonifácio - Dona Meire, seu marido já tem candidato? Dona Meire - Não sinhô, ninguém falo com nóis ainda. (esfrega os dedos polegar e indicador em sinal de dinheiro).

Capanga do Cel Bonifácio - Ah! Sim. O que a senhora precisa?

Dona Meire - Priciso de tudo.

Capanga do Cel Bonifácio - Tudo o quê?

Dona Meire - Ropa, dinheiro, remédio, carçado.

Capanga do Cel Bonifácio - Quinhentos mil réis dá pra isso, não dá?

Dona Meire - Num dá bem, mais vai remedia.

Capanga do Cel Bonifácio - Leva esse dinheiro e essas cédulas do Coronel Policarpo, dá pro seu marido e seus filhos votarem nele.

Dona Meire - Tá bem.

Assim que sai o capanga do Cel Bonifácio, chega o capanga do Cel Felinto e pergunta:

Capanga do Cel Felinto - Alguém falou com a senhora?

Dona Meire - Não.

Capanga do Cel Felinto - E esse cabra? (fazendo referência ao homem do cel. Policarpo). O que ele queria?

Dona Meire - Tava me pregutando sobre uma tar de dona Marculina, que nem sei onde ela mora.

Capanga do Cel Felinto - Seu marido tem candidato?

Dona Meire - Não sinhô, ninguém falo com nóis ainda. (esfrega os dedos polegar e indicador em sinal de dinheiro).

Capanga do Cel Felinto - Toma quinhentes mil réis e diz pro seu marido e seus filhos votarem no Coronel Felinto. 
Assim que ele sai:

Dona Meire (gargalhando) - Há, há, há, há. Que pena não ter mais candidato!!!

Assim, em meio a todas as denúncias de opressão, Mazzaropi nos diz o que o caipira, apesar de não ter frequentado a escola, como ele mesmo diz nesse filme, no diálogo com os filhos do Cel Policarpo, "não tem educação, é anarfabeto de pai e mãe", possui sabedoria e conhecimentos que lhe propiciam, utilizar-se do cômico e de uma pseudo-ingenuidade para resistir e contestar o poder instituído, exercitando sua vocação de ser mais. Segundo Paulo Freire,

Esta vocação para o ser mais que não se realiza na inexistência de ter, na indigência, demanda liberdade, possibilidade de decisão, de escolha, de autonomia. [...]. Sem a luta política, que é a luta pelo poder, essas condições necessárias não se criam. E sem as condições necessárias à liberdade, sem a qual o ser humano se imobiliza, é privilégio da minoria dominante quando deve ser apanágio seu. (FREIRE, 1995, p. 10-11).

Portanto, Mazzaropi, como Paulo Freire, jamais deixou de lutar pela transformação da sociedade e de questionar o poder dominante. Durante toda sua vida foi um operário na construção de uma sociedade igualitária, tanto do ponto de vista econômico e democrático como do ponto de vista político, racial, sexual e educacional.

O Jeca reconhece e se apropria dessa realidade que é alicerçada no conflito de classes e vale-se do filme Tristeza do Jeca como mecanismos de denúncia em favor dos que estão à margem da sociedade, mostrando-nos que só existe oprimido porque existe o opressor.

O Professor Ernani Maria Fiori, no prefácio da obra de Paulo Freire, Pedagogia do Oprimido, argumenta que:

A consciência do mundo e a consciência de si crescem juntas e em razão direta; uma é luz interior de outra, uma comprometida com a outra [...] procura dar ao homem a oportunidade de redescobrir-se através da retomada reflexiva do próprio processo em que vai ele se descobrindo, manifestando configurando - método de conscientização. (FREIRE, 1992, p. 15).

Partindo desse pressuposto, o filme Tristeza do Jeca apresenta elementos defendidos por Freire concernentes a uma conscientização do redescobrir-se no processo de descobrir a si mesmo, como sujeito inserido no processo histórico, em busca da sua afirmação. Nesse filme, verificamos a intencionalidade de fazer-se um diálogo entre as relações estabelecidas na sociedade capitalista e os valores éticos e morais constitutivos de sua identidade, buscando induzir a uma reflexão das práticas individuais e coletivas para a construção de uma sociedade mais justa e igualitária. Como nos declara Barsaline:

O que Mazzaropi fazia era manter a essência da mensagem aos segmentos populares, essência essa que contesta simbolicamente as estruturas sociais da exclusão, alterando o invólucro da manifestação cultural mudando sua aparência, conforme o publico ou o momento histórico: as modificações pelas quais passa seu Jeca efetivam a prática mesma da resistência cultural. (BARSALINI, 2002, p.84). 
Por conseguinte, Paulo Freire e o Jeca coincidem quanto à proposta em desvelar a realidade numa construção conjunta do (re)descobri-se, propiciando uma reflexão voltada para criticidade no que tange ao indivíduo como mobilizador social numa busca libertadora por uma sociedade justa.

\section{Libertação}

Com base nas discussões anteriores, compreendemos que, no método educativo e dialético preconizado por Paulo Freire, o ser humano é o agente principal, o ser de relação no e com o mundo e com os outros. Ele busca conhecer o desconhecido, a aventurar-se, para transformá-lo e transformando-se, e, ao fazê-lo, assume sua condição de ser político, de militante, de protagonista, pois "Já não se satisfaz em assistir. Quer participar". (FREIRE, 1983 p. 55). A partir desse momento, ele é convidado a tornar-se ser da práxis, em sua necessidade de buscar reinventar o mundo, isto porque ele tem a consciência de que é um ser do trabalho e, desse modo, responsável pela transformação do mundo, por meio da ação e reflexão devidamente articuladas na e pela práxis.

Salientamos que a práxis é que permite ao ser humano preparar-se para o exercício da autonomia, nos embates de sua vida. Lembramos que, para Freire, autonomia é a experiência de procura pela liberdade, por meio de caminhos permeados de desafios. Pois, mesmo tendo vocação pela liberdade, o ser humano precisa empreender uma eterna busca por espaços de autonomia, por meio de um compromisso efetivo com a causa emancipatória.

Ter liberdade, na concepção freireana, requer do ser humano o exercício da capacidade de pronunciar o mundo; é atender à vocação humana de ser protagonista de sua existência. Portanto, "a liberdade é concebida como modo de ser o destino do Homem, mas por isto mesmo só pode ter sentido na história que os homens vivem". (FREIRE, 1986, p. 6). No filme Tristeza do Jeca, os camponeses se mostram conscientes das manobras políticas que permeiam o processo eleitoral, pois, mesmo sofrendo ameaças e uma vigilância ferrenha por parte de seus patrões, conseguem valer do poder de decisão. Isso é evidenciado na cena que apresenta os colonos do Cel. Felinto indo para um rodeio organizado pelo coronel Bonifácio, mesmo contra as ordens do "patrão". Nela, vemos que os camponeses são conscientes das manobras políticas, mas desejam participar do rodeio, ter um dia de diversão, e, para isso, o Jeca, liderando o grupo leva uma placa em que está escrito de um lado "Viva o coronel Felinto!" e do outro lado "Viva o coronel Policarpo!". Assim, eles mudam a placa de lado conforme a "necessidade" e, dessa forma, escapam do controle do Cel. Felinto e se divertem no rodeio. Vejamos a cena na figura a seguir:

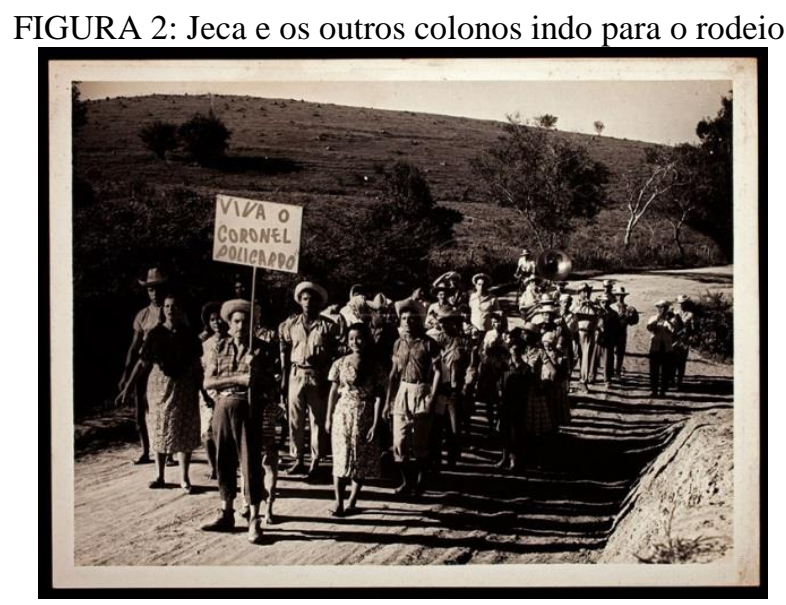

Fonte: Banco de conteúdos culturais 
Segundo Paulo Freire, "a libertação autêntica, que é a humanização em processo, não é uma coisa que se deposita nos homens. É práxis que implica a ação e a reflexão dos homens sobre o mundo para transformá-lo". (FREIRE. 1992, p. 67). Assim, a aquisição da libertação exige uma tomada de atitude, uma ação concreta não apenas pelo sujeito em si, mas em sua coletividade e organização. Identificamos essa tomada de atitude em nosso objeto de análise, em várias cenas, entre elas, a cena do rodeio e a cena em que o coronel Filinto fica sabendo que Marina, a filha do Jeca, está de namoro com o Dr. Sérgio, filho do Bonifácio, e logo compreende que é uma manobra política do adversário. Em seguida, pede para seus jagunços irem à vila dos colonos e ameaçá-los. A reação do Jeca nos mostra que ele está vivenciando a libertação preconizada por Freire. Vejam:

Jagunço: Atenção pessoal! O patrão mandou um aviso: não aceita traição. Se ele num fô eleito, todos vão fica sem trabalho e vão passá fome.

Jamanta: E agora, Jeca?

Jeca: E agora o que bobo? Isso é só ameaça.

Jamanta: Oiá, se o patrão perde nóis tamu frito!

Jeca: Cê tá pensanu que nóis dois que vai resolvê a política. Ele também precisa ter sorte.

Colono: A gente tem que fazê arguma coisa...

Jeca: Tá certo que nóis tem que fazê quarqué coisa, mais ocêis num vai pensa que o Fillinto vai cuntinuá ameaçando não. Num é cum ameaça e cum briga que ele vai consegui nosso voto.

Percebemos, desse modo, que tanto Paulo Freire como o filme Tristeza do Jeca expressam, em suas propostas, o desejo em fomentar a prática da liberdade numa perspectiva de transformação de mundo do sujeito e sua coletividade, como reconhece Barsalini, ao se referir ao Jeca:

Legítimo representante da cultura chamada arcaica, sua personagem, protagonizasse histórias que se passassem no meio rural ou no meio urbano, invariavelmente refletia o perfil de independência do trabalhador brasileiro, não se curvando ao mandonismo dos patrões, no caso das histórias rurais, ou dos doutores da cidade, no caso da histórias urbanas. (BARSALINI, 2002, p.108).

Observamos, assim, que o Jeca, como Paulo Freire, acredita que somente o oprimido pode superar a violência. Pela reflexão sobre a situação vivenciada poderá perceber a si mesmo e ao outro como pessoa e terá condições de recuperar a própria humanidade e a do opressor, na luta incessante contra o sentido de inferioridade. "Libertando-se, na e pela luta necessária e justa, o oprimido, como indivíduo e como classe, liberta o opressor, pelo fato simplesmente de proibi-lo de continuar". (FREIRE, 2007, p. 100). Entretanto, faz-se necessário que essa luta não tenha raízes na ambição por poder e no desejo de oprimir o opressor.

Ambas as produções, sejam os livros de Paulo Freire ou o filme analisado, denunciam a dialética do opressor e oprimido no que se refere à busca de uma liberdade geradora de igualdade, fraternidade e dignidade, ressaltando que recorrem a indagações, permitindo uma reflexão própria do sujeito que exercita o desvelar de sua realidade.

Ao se discutir acerca de educação e os espaços em que esta ocorre, compreendemos que a construção de saberes se tece numa relação de espaços e grupos diferenciados, com 
conceitos, características e atributos distintos. No entanto, a partir destas, cada processo educativo se complementa e contribui de forma diferenciada na formação do indivíduo.

Partindo da concepção de que a educação deve ser vista como um elemento democrático, capaz de possibilitar aos indivíduos uma participação mais ativa e concreta na sociedade, entendemos o filme Tristeza do Jeca como instrumento indispensável no processo educativo, visto que essa obra dialoga com a história artística, social, política e econômica de nosso país na década e início da 60.

Desse modo, visualizamos uma concordância dos saberes no desenvolvimento dos processos da educação não formal, identificada na filmografia analisada, com os propostos na educação popular em Freire, para quem o diálogo, a conscientização e a libertação são eixos que sustentam sua prática educativa. Além disso, ocorre uma intertextualidade entre os temas apresentados nos filmes e o que propõe Freire, no que concerne às relações entre os sujeitos das práticas educativas, de modo que, em Freire, refletimos que: "Ninguém educa ninguém, ninguém se educa a si mesmo: os homens se educam em comunhão mediatizados pelo mundo". (FREIRE, 1992, p. 68). E, "Mazzaropi vê os trabalhadores brasileiros como pessoas que pensam e agem livremente, identificando-se com a liberdade na economia, com a liberdade no trabalho". (BARSALINI, 2002, p. 25).

Conforme o que já foi exposto, consideramos que a temáticas abordadas no filme de Tristeza do Jeca são essencialmente conscientizadoras. Por meio da comicidade, é possível vislumbrarmos denúncias e críticas que nos propiciam uma reflexão sobre a realidade e, dessa reflexão surge uma aprendizagem significativa, mais comprometida com a causa social. A educação, desse modo, surge na construção dessas novas aprendizagens, a partir dessa nova forma de olhar que os indivíduos constroem sobre as relações existentes no mundo. Assim, a educação é gestada durante o processo diálogo-conscientização, confirmando o pensamento de Freire (1992) de que é pelo diálogo que se dá a verdadeira educação.

Quanto à presença da educação popular no filme em questão, Freire (1992) considera que essa concepção educativa é "Educação libertadora", porque se faz e refaz continuamente, na experiência dos oprimidos e dos que com eles se comprometem na perspectiva da transformação radical da sociedade. É o que é apresentado para o público na cena que representa o dia da eleição. Nesse dia, os empregados dos Cel. Felinto e do Cel. Bonifácio são conduzidos como um rebanho de gado, para cercados de madeira, semelhante aos currais de gado, e são colocados incomunicáveis e vigiados pelos jagunços dos respectivos coronéis até o momento do voto. No momento de votarem, saem novamente em fila, ladeados pelos jagunços, e vão depositar as cédulas com o nome do coronel, entregues antecipadamente. Marina, filha do Jeca, consegue burlar a vigilância e entrega várias cédulas com o nome do Cel. Policarpo para que seu pai as distribua entre os outros colonos. Assim, os votos vão sendo depositados na urna; alguns eleitores depositam duas cédulas, outros guardam a cédula que receberam, retiram outra do bolso e colocam na urna. Jeca debruça-se sobre a urna e coloca várias cédulas, as quais empurra com a ponta de seu guarda- chuva dizendo: "entra coroné Policarpo!".

Assim, é que o filme informa a seu público, que apesar de toda opressão e violência a que os camponeses foram submetidos, não se deixaram manipular, fazendo prevalecer a própria vontade. O Jeca, mesmo não tendo uma educação formal, nem a instrução que daí advém, é consciente do papel que os coronéis lhe atribuem no processo eleitoral, das artimanhas políticas, e "sabendo infringir as regras e reverter sua condição de manipulado. se o oportunismo existe é fruto da condição estrutural em que vive e da ausência de alternativas reais". (FRESSATO, 2009, p. 194). 
A filmografia Tristeza do Jeca se apresenta, portanto, como um espaço de educação popular, uma vez que assume um compromisso em promover práticas de formação política e sociocultural de seu público, com o desenvolvimento da consciência crítico-reflexiva e, conforme afirma Freire em relação à Educação Popular:

\begin{abstract}
qualquer esforço de educação popular, esteja ou não associado a uma capacitação profissional, seja no campo agrícola ou no industrial urbano, deve ter, pelas razões até agora analisadas, um objetivo fundamental: através da problematização do homem-mundo ou do homem em suas relações com o mundo e com os homens, possibilitar que estes aprofundem sua tomada de consciência da realidade na qual e com a qual estão. (FREIRE,1982, p.33).
\end{abstract}

Assim, nessa produção cinematográfica, o Jeca se posiciona como um educador que não se submeteu à ideologia dominante, direcionando a sua prática apenas pelo ponto de vista do oprimido. Essa é, também, a óptica básica de toda a obra freireana. Esse comprometimento com a perspectiva do oprimido podemos vislumbrar na dedicatória do seu livro Pedagogia do oprimido (1992): "Aos esfarrapados do mundo e aos que neles se descobrem e, assim descobrindo-se, com eles sofrem, mas, sobretudo, com eles lutam".

Portanto, essa produção cinematográfica de Mazzaropi, ao apresentar o contexto socioeconômico de desenvolvimento das práticas capitalistas e das injustiças sociais que permeavam a sociedade brasileira na segunda metade do século $\mathrm{XX}$, bem como os conflitos existentes nas relações no campo, inclusive a luta pela terra, imprimem essencialmente, uma base política incentivadora da superação do silêncio imposto a uma grande parcela da população brasileira, além da valorização da ideologia dessa classe. Desse modo, estimula os trabalhadores a exercitar a capacidade de direção política, a concepção pedagógica de que todos aprendem em grupo, salientando que a liberdade é uma conquista necessária e que o ser humano é capaz de resistir e defender seus valores tradicionais alicerçados na ética cristã.

\title{
Considerações finais
}

Chegamos ao término deste artigo com a certeza de que o tema não foi esgotado, apenas construímos argumentações decorrentes da pesquisa sobre a rota percorrida e o que pudemos constatar dessa trajetória. Este trabalho almeja, assim, ser apenas o primeiro filme, como aquele que deu início à produção cinematográfica de Mazzaropi. Diante disso, finalizá-la representa apenas o encerramento de uma fase e início de outra.

Desse modo, mesmo não considerando o trabalho pronto e acabado, percebemos que trilhamos os caminhos apontados pelas fontes, as quais direcionaram nosso olhar de pesquisadores. Nosso caminho privilegiou a (re)interpretação do Filme Tristeza do Jeca, com muita atenção, pois, como nos informa Xavier (1988), a interpretação de um filme é um processo em que ocorrem mediações que presentes tanto na esfera do olhar que produz a imagem, quanto no olhar que a recebe. Assim, buscamos demarcar um equilíbrio entre a valorização do objeto e sua importância histórica.

No caso do Filme Tristeza do Jeca, o que nos moveram foram as temáticas abordadas, como o coronelismo, corrupção eleitoral, além dos problemas sociais enfrentados pelos camponeses que não detêm a posse da terra. Salientamos que trabalhar com essa obra se mostrou como um grande desafio, tendo em vista que poucos pesquisadores consideram esse filme como relevante para um estudo. Acreditamos que tal 
fato se deva à falta de uma análise mais profunda, pois, em nosso trabalho, concluímos que, utilizando-se do cômico e da sátira, essa obra cinematográfica problematiza, de modo crítico e questionador, o contexto social, econômico, político e cultural vivenciado pelo homem do campo brasileiro nas décadas de 50 e início da década de 60 .

Nesse sentido, reforçando a perspectiva de análise que abraçamos nessa pesquisa a relação entre o filme Tristeza do Jeca e a Educação Popular - possibilitou um avanço para a compreensão de outras práticas educativas, que não aquelas ministradas pelo ensino formal. Constituiu-se, também, em um avanço, por edificar uma visão livre de preconceito sobre a filmografia de Amácio Mazzaropi, diferente das pesquisas acadêmicas que utilizaram como parâmetro, em sua maioria, o Cinema Novo.

Neste estudo, procuramos mostrar que o filme Tristeza do Jeca, contribui de forma vital para a historiografia brasileira. Entretanto, ele não se esgota, apresenta ainda muitos temas a serem revelados e pesquisados, uma vez que, como já citamos anteriormente, Mazzaropi foi um homem além de seu tempo. Adaptando-se a cada década, ele buscou projetar as transformações sociais produzidas e impostas pelo sistema socioeconômico, ocasionadas pela desigual distribuição de renda no país, e superou a deficiência técnica, acreditando retratar as tradições populares por meio das imagens representativas dos modos de vida de brasileiros, ao expor conflitos migratórios rural-urbanos, bem como a solidariedade, a simplicidade, a liberdade e o desejo de justiça social. Isso abre a possibilidade de estudar este filme como subsídio para a compreensão da própria realidade brasileira e os valores ideológicos que permeiam a mentalidade de nosso povo.

É importante que o pesquisador compreenda que Mazzaropi retrata em seus filmes sua concepção de mundo resultante de suas ideologias e interações sociais experenciadas. Segundo Glauco Barsalini, Mazzaropi,

Em seus filmes as contradições entre a pobreza e a riqueza são apresentadas através de dicotomias entre o amor e o ódio, as faces humanas de bondade versus maldade, humildade versus arrogância, solidariedade versus egoísmo, e conduta de consideração versus conduta de desvalorização dos valores humanos. (BARSALINI, 2001. p. 134).

Afirmamos que a produção cinematográfica Tristeza do Jeca apresenta em seu cerne uma discussão existencial acerca da justiça social. O Jeca soube representar, de modo ingênuo, muitas vezes, caricato, o contexto histórico por ele vivenciado, permeado pelas angústias do povo brasileiro sempre ameaçado pela instabilidade econômica predominante em uma sociedade cuja maior característica é a desigualdade social.

Nesse contexto, o papel do filme Tristeza do Jeca, como agente de Educação Popular, se propõe a vencer o silêncio e empreender uma luta por emancipação, no que se refere aos opressores da sociedade desigual que caracteriza nossa história. Propiciando o desenvolvimento da interação entre estes indivíduos, cujos direitos foram impedidos por uma minoria privilegiada que detém uma posição de dominação, é possível uma mobilização objetivando o desenvolvimento da conscientização e, consequentemente, garantir a sua libertação.

Concluímos, enfatizando que a literatura, a música, a fotografia e outras importantes formas de arte são partes da constituição do cinema. E, como já expusemos anteriormente aqui, a filosofia também. Afirmamos isso porque a obra de arte sempre se submeteu ao objeto de reflexão filosófico, conseguindo uma posição ativa de agente transformador em questões filosóficas. O cinema, como arte industrial, tem obedecido a sua função. O filme Tristeza do Jeca é apenas uma das produções cinematográficas de 
Mazzaropi que revelam uma filosofia em sua essência, e atuam como mecanismos de educação popular. É certo que, neste novo século, mais difícil se torna a aceitação de uma visão filosófica pela massa social, mesmo quando se trata de cinema, mas não há como negar a grande contribuição que esta arte trouxe para as três últimas gerações.

O que expusemos neste artigo sintetiza os resultados da nossa investigação sobre a relação entre o filme Tristeza do Jeca e sua contribuição para a educação do povo brasileiro. Não temos, em nosso trabalho, a pretensão de formular questões inovadoras ou de esgotar o assunto, mas consideramos que esse recurso audiovisual é um potencial que não deve ser menosprezado pelos pesquisadores que objetivam refletir sobre a história, sobre a sociedade, sobre os comportamentos humanos e as formas de os homens educaremse.

Refletir sobre a função da educação e fornecer elementos para a exploração de fontes alternativas para as atividades de ensino e pesquisa são passos indispensáveis para abrir novas possibilidades e perspectivas de aprendizagem e investigação na sociedade contemporânea. Neste sentido, este ponto final mais do que a representação do término de uma pesquisa, aponta-nos um amanhã que se faz necessário.

\section{Referências}

BARSALINI, GLAUCO. Amácio Mazzaropi: crítico de seu tempo. Campinas. São Paulo [s. n.]. 2001. Disponível em:

<http://www.bibliotecadigital.unicamp.br/document/?code=000205479>. Acesso em 18 de junh de 2012.

BARSALINI, Glauco. Mazzaropi: o Jeca do Brasil. Campinas, SP: Editora Átomo, 2002.

FREIRE, Paulo. Educação como prática da liberdade. 10 ed. Rio de Janeiro: Paz e Terra, 1986.

Pedagogia da autonomia: saberes necessários à prática educativa. 30 ed. São Paulo: Paz e Terra, 2004 (coleção Leitura).

. Conscientização: teoria e prática da libertação. Uma introdução ao pensamento de Paulo Freire. São Paulo: Moraes, 1980.

Pedagogia da esperança: um reencontro com a pedagogia do oprimido. 14 ed. Rio de Janeiro: Paz e Terra, 2007

Terra, 1981.

Ação Cultural para a Liberdade e outros escritos, 5 ed., Rio de Janeiro,Paz e

. Pedagogia do oprimido. 20 ed. Rio de Janeiro, Paz e Terra, 1992

Extensão ou Comunicação?, 6 ed., Rio de Janeiro, Paz e Terra, 1982.

Educação e Mudança, 4 ed., Rio de Janeiro, Paz e Terra, 1981 
FRESSATO, Soleni Biscouto. Caipira sim, trouxa não: Representações da cultura popular no cinema de Mazzaropi e a leitura crítica dos conceitos pelas ciências sociais. 2009. 282 f. Tese (Doutorado). Universidade Federal da Bahia, Faculdade de Filosofia e Ciências Humanas. Salvador. 2009. Disponível em: <http://www.ppgcs.ufba.br/site/db/trabalhos/2632013115030.pdf $\geq$. Acesso em 23 julh 2012.

ORTIZ, Renato. Cultura brasileira e identidade nacional. 5aed. São Paulo: Brasiliense, 2003. . Românticos e folcloristas. Cultura Popular. São Paulo: Olho D’Água, 1992.

XAVIER, Ismail. Cinema: revelação e engano. In: NOVAES, Adauto et al. O olhar. São Paulo: Companhia das Letras, 1988.

Filme

TRISTEZA DO JECA. Direção: Amácio Mazzaropi. Produção PAM Filmes. Taubaté SP, 1961. 95 min. Son, Color, Metragem: 2.650 m.

\section{Fotografias}

AMARAL, José. Tristeza do Jeca. 1961. Fotografia, p \& b, 18x24 cm. Código: FB_0711_022. In: Banco de Conteúdos Culturais. Disponível em:

$<$ http://www.bcc.org.br/fotos?page=1\&field_xmp_headline_value=tristeza $\% 20 \mathrm{do} \% 20 \mathrm{jeca}$ \&field_xmp_scene_value>. Acesso em: 06 de jan 2014.

. Tristeza do Jeca. 1961. Fotografia, p \& b, 18x24 cm. Código:

FB_0711_023. In: Banco de Conteúdos Culturais. Disponível em: $<$ http://www.bcc.org.br/fotos?page $=1 \&$ field_xmp_headline_value $=$ tristeza $\% 20$ do $\% 20$ jeca \&field_xmp_scene_value>._Acesso em: 06 de jan 2014.

Notas

${ }^{1}$ Este trabalho resulta do estudo realizado durante a pesquisa desenvolvida no Mestrado em Educação (20122013), na linha História e Historiografia da Educação, pela Universidade Federal de Uberlândia.

2 Mestre em Educação, na linha História e Historiografia da Educação, da Universidade Federal de Uberlândia. Uberlândia/MG. E-mail: juscimarmaria@ hotmail.com.

3 Doutor em Educação pela UNICAMP e docente do curso de Mestrado em Educação da UFU Universidade Federal de Uberlândia. Uberlândia/MG. E-mail: Armindo@pontal.ufu.br

\footnotetext{
${ }^{4}$ Segundo Fressato (2009), este foi o primeiro filme colorido de Mazzaropi, em Eastmancolor, com revelação e trucagem realizadas na Cidade do México. E o primeiro filme desse cineasta exibido na televisão brasileira, no Festival de Cinema Brasileiro da extinta TV Excelsior. Além disso, essa película ganhou os prêmios: Cidade de São Paulo, melhor ator coadjuvante para Genésio Arruda e melhor música para Hector Lagna Fietta. A ficha técnica completa, o elenco e enredo encontra-se disponível em: <http:// www.museumazzaropi.com.br/bios/mazza.htm> Acesso em: 16 jul. 2012.
} 
5 Amácio Mazzaropi nasceu em São Paulo, SP, em 09 de abril de 1912. Filho do Italiano Bernardo Mazzaropi e da Taubateana, Clara Ferreira Mazzaropi. Aos dezesseis anos, foge de casa.. Em 1940, monta o Circo Teatro Mazzaropi e cria a Companhia Teatro de Emergência. Em 1948, vai para a Rádio Tupi., Em 1950, inaugura a televisão no Brasil e para lá leva seu programa, com estrondoso sucesso. Participa de oito filmes como ator contratado e, em 1958, funda a Pam Filmes, Produções Amacio Mazzaropi. A partir daí, passa a produzir e dirigir seus filmes. Lança um filme por ano e sempre em 25 de janeiro, aniversário de São Paulo Fica milionário. No início dos anos 70, constrói novos estúdios e um hotel, também em Taubaté. Artista nato e empresário com muito tino comercial, morre em 13 de junho de 1981, aos 69 anos de idade, vítima de câncer na medula, logo após iniciar sua 332 produção, JECA E A MARIA TROMBA HOMEM. Disponível em: <http:// www.museumazzaropi.com.br/bios/mazza.htm> Acesso em: 16 jul. 2012.

${ }^{6}$ A Educação Popular, na versão em que a conhecemos no Brasil e na América Latina, ao longo dos últimos cinquenta anos, inspirada, originalmente, na obra e na prática política de Paulo Freire, vem passando por marcantes transformações. Seu caráter militante e engajado, seus fortes vínculos inicias com Movimento de Cultura Popular (MCP) e o Movimento de Educação de Base (MEB) da Igreja Católica, entre outros que emergiam na década de sessenta, vão sendo nuançados por outras aproximações políticas - como, por exemplo, do Movimento dos Sem Terra (MST) - misturando-se aos matizes dos mais diversificados movimentos sociais populares deste final de milênio. Com manifestações em vários continentes, a Educação Popular continua se caracterizando por suas vinculações com grupos populares, entendidos, estes, como segmentos populacionais marcados por discriminações, por diferentes formas de exclusão e marginalidade social. Trata-se, assim, da educação que tem se ocupado dos "pobres" e, como diria Freire, dos oprimidos. (COSTA, 1998, p. 9-10).

7 O coronelismo representou uma variante de uma relação sociopolítica mais geral - o clientelismo -, existente tanto no campo como nas cidades. Essa relação resultava da desigualdade social, da impossibilidade de os cidadãos efetivarem seus direitos, da precariedade ou inexistência de uma carreira no serviço público. [...]. Do ponto de vista eleitoral, o "coronel" controlava os votantes em sua área de influência. Trocava votos em candidatos por ele indicados por favores tão variados como um par de sapatos, uma vaga no hospital ou um emprego de professora. (FAUSTO, 1994, p. 263).

${ }^{8}$ Nome como é chamado um dos colonos.

Recebido: março-14 Aprovado: janeiro-15 